\title{
Leksem cud i jego derywaty w historii polszczyzny
}

Celem artykułu jest analiza zmian znaczeniowych derywatów rzeczownika cud, a także ustalenie prymarnych przyczyn poszczególnych przesunięć semantycznych.

Główny kierunek analiz wyznacza metoda semazjologiczna. Wychodząc od etymologii, pokażę, w jaki sposób poszczególne słowoformy nabywały nowych treści, które sensy były dominujące, a które pojawiały się marginalnie.

Po dokonaniu wstępnych obserwacji zauważyć można, że zebrane leksemy ${ }^{1}$ koncentrują się wokół dwóch pól znaczeniowych: 1. 'zjawisko nadprzyrodzone'; 2. 'coś dziwacznego, głupiego, kuriozalnego'. W nawiązaniu do tych kategorii porządkowane będą analizowane jednostki.

\section{Jednostki implikujące zjawisko nadprzyrodzone}

\subsection{Leksem cud}

Leksem cud swymi korzeniami sięga praindoeuropejszczyzny. Jego etymonem jest pie. pierwiastek *(s)keu- 'zwracać uwagę, odbierać wrażenie zmysłowe' [SBor], stanowiący podstawę greckiego kỹdos, kỹdeos 'cześć, sława' [SBor], łacińskiego tundo, tundere 'bić, uderzać, thuc', węgierskiego csod'a 'cud' [SBań] oraz oczywiście psł. rzeczownika *tjudo lub čudo, čudesse o znaczeniu 'zdziwienie, podziw; coś zadziwiającego' [SSław, SBań, SBor].

Zdaniem Andrzeja Bańkowskiego [SBań] przywołane wyżej znaczenie prasłowiańskiego wyrazu było wtórne, prymarnie psł. $\dagger$ tjudo stanowił bowiem nazwę uderzenia pioruna. Następnie treść 'grzmot, błyskawica' uległa generalizacji, zyskując postać 'dziwny znak na niebie', a jeszcze później 'to, co

1 Jednostek tych odnotowano 50. 
zadziwia, zdziwienie' [SBań]. Etymolog wyraźnie podkreśla, że postać čudo, čudesse to rosyjska innowacja morfologiczna wygenerowana jako przeciwwaga dla wcześniejszego $† k u d o, k u d e s s e$ 'gusła magiczne, szamańskie' [SBań]. Forma čudo, čudesse, znacząca 'prawdziwe cuda Jezusa', przejęta została natomiast około XIV wieku przez polszczyznę.

Referowanej hipotezy nie podziela jednak Wiesław Boryś [SBor], który zakłada, że bez wątpienia już w prasłowiańszczyźnie istniała formacja *čudo, čudesse 'coś budzącego podziw, zjawisko nadprzyrodzone' [SBor], a na gruncie polskim przerodziła się w $c z u d o^{2}$.

Niezależnie od tego, którą spośród tych hipotetycznych ścieżek etymologicznego rozwoju badanej formacji przyjmiemy, nie ulega wątpliwości, że począwszy od XIV wieku, w polskich tekstach notowane są postaci $c z u d o$ i cudo. Obecność drugiej formy wszyscy polscy etymolodzy zgodnie thumaczą mazurzeniem [SBr, SSław, SBań, SBor].

Staropolska treść leksemu czudo (cudo) stanowiła wierne odzwierciedlenie biblijnego rozumienia terminu miraculum 'zjawisko nadprzyrodzone, cud, uzdrowienie, znak uczyniony za sprawą Boga'. Fakt ten nie zaskakuje, wszak teksty XIV-XV wieku to w większości zabytki sakralne, np. „Czuda wielika czyny” [Błaż. 319, SStp]; „Maria rzekła k’ niemu: Dziękuję Bogu memu, iże jemu tako ljubo uczynił we mje to czudo" [XV med. PF IV 594, SStp]. Niemniej zdarzało się, że już w staropolszczyźnie odnoszono cudo również do rzeczy dziwnej, niespotykanej, niekoniecznie uczynionej za sprawą Boga, np. „Jeden z tych krolow widział stroża..., a gdyż juże zniosł... jajca, wtedy wielikie czudo stało się z tych jajec (monstrum exit ab ovis), bo z jednego wskoczył lew, a z drugiego baran" [Rozm. 72, SStp].

Zdecydowanie więcej podobnych użyć odnotowano w XVI wieku. W tym jednak czasie zmienił się rodzaj gramatyczny wyrazu cudo z nijakiego na męski - cud (długo jednak funkcjonowały obie postaci leksykalne, analogicznie do form brzuch : brzucho, piekt : piekło, ud : udo [SSław]). Wraz z zasygnalizowaną modyfikacją doszło do generalizacji znaczenia badanej formacji. Nadal jednak wszystkie jej sensy koncentrowały się wokół podstawowej treści 'zjawisko nadzwyczajne, przypisywane siłom nadprzyrodzonym'. W zależności od kontekstu mógł zatem leksem cud oznaczać 'działanie Jezusa Chrystusa, tj. np. uzdrowienia, rozmnożenie chleba i ryb, cud w Kanie Galilejskiej’, 'niewiarygodne zdarzenia dokonywane za sprawą domniemanych świętych' (np. „Przy śmierci Ladysławowej wiele się cudow działo” [Hist. Kron. 301 v,

2 Taka sama informacja zawarta została we wcześniejszych słownikach etymologicznych, w leksykonie Aleksandra Brücknera [SBr] oraz u Franciszka Sławskiego [SSław]. 
25 marg. [85 2], SXVI]; „,iż Pan Bog przez święte prochy, przez kości, i przez insze świętych ludzi relikwie, tyż cuda dziwnym obyczajem sprawuje" [Kuczb. Kat. 275, SXVI]), 'stworzenie, istotę osobliwą, dziwną, nienaturalną, potwora' (,z trzecim zaś razem pokusę albo cudo jakieś okrutnie straszliwe z kozią głową, a na kształt ognia z pałającymi oczyma wyciągnęli” [Stryj. Kron. 35, 351 marg., SXVI]) lub 'morskie zwierzę, o którym w dobie średniopolskiej niewiele wiedziano' (np. „Dzień ku robocie człowiekowi. Cuda morski. Cete, abo wieloryb" [Lub Ps X6 marg., SXVI]). O ile motywacja sensów wiązanych z Bożą ingerencją wydaje się oczywista, o tyle wyjaśnienia wymagają znaczenia 'potwór' i 'morskie zwierzę'. Treści te rozwinęły się na skutek przeniesienia psł. sensu 'to, co dziwi, jest osobliwe' na 'istotę, której wygląd może budzić zaskoczenie'. Warto jednak zauważyć, że znaczenie 'potwór' zainicjowane zostało już w cytowanym wyżej fragmencie Rozmyślania przemyskiego.

Incydentalnie zdarzało się także, że wyraz cud w XVI wieku występował w znaczeniu ironicznym, jako określenie absurdalnej rzeczywistości, np. „Słyszałem ministra jednego każącego na tę Ewangelią, iż Luter uczynił cudo wielkie to: iż za kilka lat i rychlej wszytki klasztory panieńskie i mniskie w Saskiej ziemi spustoszył" [Skar. Kaz 418b, SXVI]. Niemniej podobnych poświadczeń było w tym czasie niewiele.

W kolejnym stuleciu coraz częściej badany wyraz stanowił nazwę 'czegoś dziwnego, a niewiązanego ze zjawiskami nadprzyrodzonymi’, np. „Bogacz Michał kuśnierz mieszczanin Krakowski w nędzy umarł [...]. Cud to beł, bo bogacz w nędzy umary" [Trep Nek Lib 32, SJPXVII].

Ukonstytuowane zostały nawet $\mathrm{w}$ tym czasie frazeologizmy typu: robić cuda i czynić cuda, które w licznych kontekstach miały nacechowanie ironiczne. Obie jednostki rozumiano jako 'robić dziwne lub straszne rzeczy', np. „Jam sobie pił na fantazyją i czeladzi swojej dawać kazałem a po tym z pijanemi ich pacholarzami cuda robili w nos im papier zapalali, wąsy im rożnemi rzeczami smarowali” [Pas Pam 229, SJPXVII]; „Cuda robili kozacy nikomu nie folgując białogłowy ścinając, dzieci rozdzierając i cokolwiek najgorszego wyrządzając im" [Pas Pam 276, SJPXVII].

Zdesakralizowany sens 'rzecz dziwaczna, kuriozalna' rozwinął się na skutek skojarzenia cudu jako 'czegoś niewiarogodnego, kwestionującego prawa natury' z „czymś”, co stanowi zaprzeczenie praw zdrowego rozsądku. Początkowo jednak użycie leksemu cud w takim znaczeniu było po prostu hiperbolą, wnoszącą sporo ironii. $Z$ czasem znamiona wyolbrzymienia stopniowo rugowano.

Nie znaczy to, że w XVII wieku zapomniano o pozostałych, XVI-wiecznych treściach rzeczownika cud. Nadal dominujące było znaczenie 'nadzwyczajne zjawisko interpretowane jako skutek Bożej działalności’, np. „[Siostra Cecy- 
lia -Z.K.] wielu cudów Boskich oczywistym świadkiem, przez modlitwę świętego Dominika uczynionych była [...]" [Okol. Niebo 4, SJPXVII]; ,[...] cuda czynić na świecie, Jego [Boga - Z.K.] jest robota. Jego palcem Chrystus Pan, Chrystusowym ludzie czynili, byli który znaczny w jakim cudzie" [Pot. Frasz. Brück. II 11, SJPXVII].

Podobnie jak w XVI wieku rzeczownik cud występował również w funkcji nazwy potwora (np. „Tedy mój, nie na wojnę, na strzały, na miecze, syn jedzie? Lecz na obrok obrzydłego cuda, niech się nad nim ta sprośna, nie pastwi paskuda [...]” [Pot Per 20, SJPXVII]) oraz morskiego ssaka (np. „Trzeci znak, iż wszytkie bestie i cuda abo poczwary morskie, zgromadzą się do kupy, i ryczeć będą aż pod niebiosa [...]" [Star. Kaz. 604, SJPXVII]).

Po raz pierwszy odnotowane zostały natomiast $\mathrm{w}$ tym okresie takie znaczenia, jak 'coś pięknego', 'zdziwienie, podziw'. Obie treści, mające skądinąd charakter metaforyczny, wiązane były prymarnie z wrażeniami obserwatora cudu, który, widząc coś nadzwyczajnego, skojarzył to zjawisko z innymi, podobnymi wrażeniami, np. z „czymś” pięknym lub z zauroczeniem, ze zdziwieniem. Niewykluczone także, że cud zyskał treść 'piękno' pod wpływem leksemu cudność, będącego już w staropolszczyźnie synonimem piękna (o czym jeszcze będzie mowa):

cud 'coś pięknego': Jużeś ty u mnie dawno cudem i te gładkości twojej dziwy znamienite: Cud są postępki, cud są wszytkie cnoty, dziw głos, dziw postać, dziw insze przymioty [...]. [Morsz. A. Utw. Kuk. 245, SJPXVII]

cud 'zdziwienie, podziw': Bromę w herbie twym, ciebie: zbrojne widząc w bromie, stanąłem wielkim cudem zadumany, bo mię i strach ujął, przyznam się, skąd tak nagła wojna? Miecz w ręku, w których dotąd, krowa była dojna? [Pot. Pocz. 123, SJPXVII]

Tak wielką zdobycz odniósłszy bez trudu, dłużej tu zdrajcy nie myślą się bawić, bowiem nie może wyniść im to z cudu [...]. [Pot. Syl. 86, SJPXVII]

Na uwagę zasługuje zwłaszcza trzeci fragment, w którym zawarty został właściwy dla połowy doby średniopolskiej frazeologizm nie móc wyniść komuś z cudu (mający obecnie postać nie móc wyjść z podziwu). Jak się wydaje, związek ten w XVII wieku był dość często używany i pewnie dlatego element cud z czasem „oderwał się” od ukonstytuowanej struktury tegoż zwrotu i stał się predykatem o znaczeniu 'to niewiarygodne, że', np. „Cud, że nie możem ślepemu [Kupidynowi - Z.K.] dać rady, który nie widzi strzały swojej końca, 
i że przezorne pozwalają nieba strzelać dziecięciu nie tam, gdzie potrzeba" [Morsz. A. Utw. Kuk. 38, SJPXVII].

Poza predykatem rzeczownik cud mógł też występować w funkcji przysłówka - tj. cudem. W tym jednak przypadku doszło do scalenia rejestrowanego wcześniej wyrażenia cudownym sposobem w formie N. lp. Derywat semantycznie wiązany był z całym związkiem frazeologicznym, będącym jego podstawą, a zarazem jedyną możliwą parafrazą słowotwórczą [zob. Janowska 2000: 191], np. „[...] zdarzył P. Bóg cudem wielkim, że lubo trzy miał w tym [mieście - Z.K.] nieprzyjaciel meczety, poddał się tej nocy, tj. czwartego tylko dnia od obsydii, na imię moje, lubo nasze wojska, prócz brandenburskich, w to się nie mieszały, dla słabości i chorób" [Sob. J. Listy 573, SJPXVII]. Znaczenie badanego przysłówka nie zmieniło się, nadal charakteryzuje on czynność dokonującą się w sposób niepojęty.

Około XVIII wieku doszło z kolei do niewielkiej modyfikacji semantycznej rzeczownika cud. W artykule hasłowym SL wyraz ten zawiera tylko dwa, niezwykle rozbudowane sensy, tj. 1. 'zdarzenie dziwne, nadzwyczajne, którego przyczyny nie dochodzą' oraz 2. 'rzecz dziwna, nadzwyczajna' [SL]. Z cytatów ujętych w tym leksykonie można jednak wywnioskować, że nadal wyraz cud odnoszono do: działań Jezusa Chrystusa i świętych; zjawisk, osób i rzeczy niezwykle pięknych; zdarzeń zaskakujących. Wyrugowane zostały natomiast sensy o konotacjach ujemnych, tj. 'straszne, niegodziwe rzeczy', 'potwory'. Taki stan rzeczy utrzymuje się nadal.

Dość istotnie zmieniło się natomiast znaczenie wyrażenia ósmy cud świata, odnotowanego na przełomie XVII i XVIII wieku. Jeszcze pod koniec XIX stulecia [SKras] związek ten stanowił synonim frazeologizmu cud nad cudami, tj. 'coś nieprawdopodobnego', por. np. „Będzie ósmy cud świata, jeśli on pić przestanie” [Oss. Wyr, SL]; „Po wszystkim wojsku naszym i cesarskim udano było, żem poległ na placu; jakoż że się to nie stało, jest to cud nad cudami [...]" [Sob J Listy 554, SJPXVII]. Od początku XX wieku ósmy cud świata znaczy natomiast 'coś nadzwyczajnie pięknego' (np. „Mistrz-kredencerz przyniósł tymczasem dwa puchary z weneckiego kryształu, roboty tak cudnej, że za ósmy cud świata mogłyby uchodzić" [Sienk. Pot. IV, 86, SL]), z kolei cud nad cudami od połowy tego stulecia nie jest rejestrowany.

W dobie średnio- i nowopolskiej dość popularne były także luźne kolokacje z elementem cud, tj. cud w dziełach rymotwórczych [SL], cud sztuki [SWil], cud waleczności [SKras], cud piękności [SKras], cud doskonałości [SKras]. Do czasów obecnych przetrwały tylko dwa ostatnie związki pochodzące ze SKras.

Od początku XVII wieku niezmienione znaczenie ma wyrażenie siedem cudów świata („W tymże mieście [Olimpii - Z.K.] był Kościół Jovis Olympii, 
którego cudna statua, między siedm cudów świata policzona" [Chmiel Ateny II 438, SJPXVII]) oraz zwrot cuda wyrabiać 'robić dziwne, osobliwe rzeczy' (np. „Cuda wyrabiał na weselu, skakał, pląsał, koziołki wywracał” [Oss. Wyr, SL]).

Za najnowsze frazeologizmy z wyrazem cud uznaje się z kolei związki: cudów nie ma 'niemożliwe, nie może się zdarzyć' [SD], dokonać cudu 'zrobić coś niezwykłego' [SD], cud miód (ultramaryna) 'o kimś lub o czymś nadzwyczajnym, doskonałym, pięknym' [USJP] oraz cuda niewidy 'o czymś (rzekomo) niezwykłym, rzadko spotykanym, niesamowitym’ [USJP].

\subsection{Przymiotniki cudny, cudowny}

Zaskakujące jest to, że znaczenie strukturalne przymiotnika cudny (czudny, powstałego na bazie rzeczownika czudo), tj. 'dotyczący cudu, związany z cudem', nie zostało poświadczone w staropolskich tekstach. Od początku swej historii derywat ten stanowił polski odpowiednik takich łacińskich przymiotników, jak: pulcher 'piękny' (np. „O Anno święta, rożdżka barzo cudna i z siebie wypuszczająca" [MW $60 \mathrm{a}$, SStp]) oraz perfectus 'doskonały' (np. „Na pamięci miej wszystkie objety i objeta twoja cudna bądź” [Puł. 19, 3, SStp]). Przywołane wyżej znaczenia miały bez wątpienia charakter przenośny. Wydaje się jednak, że początkowo przymiotnik cudny wiązano przede wszystkim z osobą świętą, dokonującą cudu, której przypisywano przymiot piękna i doskonałości zarówno duchowej, jak i fizycznej.

W XVI wieku leksem cudny zaczęto natomiast odnosić do urodziwych ludzi, gładkiej cery (np. „Też tak sama miętka jedzona surowo, płeć czudną daje temu człowiekowi ktory jej często pożywa" [Fal Zioł I 82b, SXVI]), zwierząt (,A naczudniejszy koń gdy go szpetną a zdrapaną gunią skryją tedy i oszpetnieje" [Rej Zwierc 54, 13v, 47, 71, 84v, 89v, SXVI]), śpiewu ptaków, eleganckich, kształtnych oraz gustownych przedmiotów, również do dobrych uczynków oraz osób wykonujących te uczynki (,skąd możem to rozumieć, że im kto cudniejszy, tym niejako być musi Bogu podobniejszy" [Koch. Dz. 106, SXVI]) - innymi słowy, do wszystkiego, co dobre, piękne i doskonałe. Taka treść utrzymała się do dziś (por. cudny 'niezwykle piękny, śliczny, czarujący, godny podziwu; zadziwiający, nadzwyczajny’ [USJP]), niemniej jednak obecnie frekwencyjnie częściej stosuje się synonim przymiotnika cudny (USJP uznaje leksem cudny za książkowy) - wyraz cudowny.

Jednostka ta po raz pierwszy zarejestrowana została w XVI wieku w trzech znaczeniach: 1. 'nadzwyczajny, przypisywany działaniu sił nadprzyrodzonych' (np. „Temiż czasy przez trzy niemal godziny, cudowne ciemności świat wszystek pokryły" [Lat. Har. 320, +8v, 33, 84, 92, 252 (22), SXVI]), 2. 'czy- 
niący cuda' (np. „Żadna sekta nie miała nigdy tak ludzi świętych i cudownych i umartwionych światu i ciału jako chrześcijańska" [Skar. Kaz. 277a, SXVI]) oraz 3. 'zacny czcigodny' (np. ,,Ten Teodozjusz [...] więtsze zwycięstwa niźli ktory nacudowniejszy i nawojenniejszy krol przez swoje hetmany, otrzymawał" [Skar. Kaz. Sej. 681a, SXVI]). Ostatnie znaczenie rozwinęło się na podstawie sensu 'czyniący cuda', przez skojarzenie cudotwórcy z okazywanym mu szacunkiem. Należy jednak wyraźnie zaznaczyć, że w XVI wieku leksemy cudny i cudowny nie miały wspólnych sensów.

Sytuacja zmieniła się w kolejnym stuleciu. Wówczas przymiotnik cudowny zyskał nową treść - 'zachwycający, zadziwiający', np. ,Za pałacem fontanny misterne a prawie cudowne, wciąż wielkiego podwórza, pierwsza we środku: atlas świat dźwigający, grota nad nim wielka" [Zawisza Pam. 93, SJPXVII]. W takim jednak użyciu badany wyraz do końca XVIII wieku stosowany był marginalnie i nawet $\mathrm{w}$ artykule hasłowym przymiotnika cudowny, ujętym w SL, sens 'piękny' nie został odnotowany.

W SWil i SW natomiast znaczenie 'cudny, dziwnie piękny' sytuuje się dopiero na czwartym miejscu (za 'słynący cudami' i 'zadziwiający przez osobliwość, nadzwyczajny'). Do utożsamienia jednostek cudny i cudowny doszło zatem dopiero w połowie XX wieku. Nadal jednak cudowny poza 'czymś niezwykle pięknym, godnym podziwu' charakteryzuje też rzeczy, miejsca 'słynące cudami, powstałe na skutek cudu', także osoby 'tworzące, robiące cuda'. Całkowicie wyparty został natomiast właściwy dla XIX i początku XX wieku sens 'dziwak, cudak' [SWil, SW].

\subsection{Rzeczowniki cudność i cudowność}

Na bazie przymiotnika cudny powstał w XV wieku rzeczownik cudność 'piękno, doskonałość, dobroć, zacność' [SStp]. Już w staropolszczyźnie wyraz ten miał dość szeroki zakres użyć, bowiem stosowano go nie tylko w odniesieniu do Bożych przymiotów, ale również do dobrych manier i obyczajów, np. „Między pannami we cudności rosła ku obrzędu” [1453 R. XXV 211, SStp].

W XVI wieku z kolei leksem cudność pełnił najczęściej funkcję synonimu urody (np. „Iż włosy dane ku okrasie cudności człowieka” [Glab. Gad. A 7, SXVI]). Jeśli natomiast odnosił się do piękna duszy, wymagał uszczegółowienia w postaci odpowiedniej przydawki, np. duszy, obyczajów, np. ,a będzieszli grubej twarzy, patrz aby to zawetował cudnością dusze to jest cnot i dobrych obyczajow" [Biel. Żyw. 35, SXVI]. Nie powinno dziwić zatem to, że już w XVIII wieku sensy wiążące cudność z walorami duchowymi zostały wyrugowane. Warto jednak zauważyć, że znaczenie 'uroda' uległo także modyfikacji semantycznej. Pod koniec doby średniopolskiej cudnością nazywano wszak 
niebywałe, niepodlegające dyskusji piękno fizyczne, np. „Król chciał okazać cudność królowej, albowiem była nadobna" [Radz. Est. 1, SL]. W takim znaczeniu badany wyraz funkcjonował do końca swojej historii - do połowy $\mathrm{XX}$ wieku [SD].

Na początku tego stulecia natomiast synonimem leksemu cudność stał się wyraz cudowność (powstały od cudowny). Początkowo ten, poświadczony po raz pierwszy w XIX wieku, rzeczownik rozumiany był wyłącznie jako 'moc cudów’ (por. np. „Cudowność obrazu, cudowność relikwii” [SWil]). Sukcesywnie jednak jego treść zbliżyła się do podobnie brzmiącej nazwy cudność, w rezultacie w SW hasło cudowność zdefiniowane zostało jako 'rzecz cudowna', 'piękność', natomiast w SD - 'to, co jest cudowne; bycie cudownym, atmosfera otaczająca rzeczy cudowne'. Przywołane znaczenie utrzymuje się nadal.

\subsection{Przysłówki cudnie i cudownie}

Utworzony w staropolszczyźnie przysłówek cudnie w dobie staro- i średniopolskiej zawierał treść zbliżoną do swej słowotwórczej bazy, w zależności od kontekstu charakteryzował bowiem sposób wykonywania czynności, który mógł być: piękny („Im ci człowiek jest piękniejszy, tym w sercu gorszy, a przez to, im ci miły [...] człowieka cudnie stworzy, tym ci się rychlej grzechu dopuści [...]” [Gn. GL 70 b, SStp]; „Nie słuchaj nigdy pochlebce: Acz ci cudnie rzecz prowadzi, ale cię na końce zdradzi” [Bier. Ez. K3, SXVI]), doskonały, solidny (np. „Dom cudnie murowany, gdzie albo marmurem albo sztukwarkiem ściany, albo strop kwiaty pozłacanemi osadzono" [Gorn. Sen. 236, SL]), wytworny, przyjemny (np. „Będziem sobie u ognia siedzieć przy kominie: i cudniej nam daleko noc niźli dzień minie” [Pudł Fr 31, 21, 70, 79, SXVI]), grzeczny (np. „Pozdrowienie gdy jej dawał cudnie się z nią jest rozmawiał archanioł Gabriel" [XV p. post. R. XIX 56, SStp]).

Jego XX-wieczny synonim - przysłówek cudownie analogicznie do przymiotnika cudowny (jego słowotwórczej bazy) początkowo miał inną treść. Do końca XIX wieku rozumiano go jako 'przez cud; za sprawą cudu', np. „Acz P. Bóg cudownie Piotra wybawił; wszakoż nie chciał Piotr Boga kusić” [Wuj. NT, SXVI]; „Święty Piotr cudownie uwolniony był z więzów od Anioła” [SWil].

Co ciekawe, ta pozornie stabilna treść nie została poświadczona w SW. W leksykonie tym przysłówek cudownie traktowany jest jako równoznacznik formacji cudnie. Nie można jednak wnioskować o tym, że sens 'cudem' został wyrugowany ze znaczenia leksemu cudownie. Nadal bowiem możliwe są użycia typu: „Ocaleć cudownie z pożaru”, „Cudownie wyzdrowieć”. Zdecydowanie częściej jednak badany przysłówek oznacza 'bardzo dobrze, korzystnie', np. „To cudownie, że udało ci się przyjśćc [USJP]; ,Rana cudownie się goi” [USJP]. 


\subsection{Kompozycje cudoczyńca, cudotworca, cudotwórczyni, cudotwórczyna ${ }^{3}$} Począwszy od XVI wieku, w polszczyźnie funkcjonują kompozycje cudoczyńca i cudotworca, stanowiące nazwy wykonawców czynności, zajmujących się robieniem cudów. Jednostki te zbudowane są podobnie: za pomocą sufiksu -ca (tworzącego od prasłowiańszczyzny nazwy wykonawców czynności), rzeczownikowej podstawy cud, czasownikowej bazy znaczącej 'budować, wykonywać' oraz interfiksu -o-.

Analizowane formacje prymarnie były tłumaczeniami obcych wyrazów pojawiających się w tekstach sakralnych ${ }^{4}$ (ale nie stanowiły wiernych kalek tych leksemów [Puzynina 1961: 147, Handke 1976: 75]). Najczęściej odnosiły się do postaci Mojżesza, Chrystusa, apostołów, rzadziej do osób świętych, np. ,Jako chorążowie tej piechoty byli wielcy apostołowie, i oni synowie pierworodni, one Ducha S. pierwiastki, cudotworcy” [Skar. Żyw. [407], SXVI]; „Oni w tak wielkim uporze zostali, iż się cudotworcę Mojżesza bać zapomnieli" [Skar. Żyw. 493, SXVI].

Zdarzały się jednak już na tym etapie rozwoju polszczyzny użycia, w których leksemy cudoczyńca i cudotwórca miały ironiczne nacechowanie, znaczyły bowiem 'oszustów' i 'szarlatanów', np.: „Sam Mojżesz pisze, i uczy o tym jako doświadczać, fałszywych i prawdziwych prorokow” [Czech. Rozm. 104, SXVI].

W kolejnych stuleciach wyraz cudoczyńca nie był już rejestrowany, natomiast cudotwórca zdecydowanie częściej oznaczał 'matacza'. W SW nawet zdefiniowany on został jako 'cudodziej, ten co czyni cuda, czarnoksiężnik'. Można by było zatem przypuszczać, że pod koniec XX, na początku XXI wieku staropolski sens 'osoba mająca dar czynienia cudów' zostanie zapomniany, a jedynym znaczeniem formacji cudotwórca będzie 'magik, kuglarz'. Tymczasem w SD za prymarne znaczenie uznana została treść strukturalna badanej jednostki (tj. 'ten, kto tworzy cuda', por. też „Jedni mówili, że legat papieski przyjechał, drudzy, że jakiś cudotwórca, co leczy chorych i wskrzesza umarłych" [Kaczk. Oblarch. II, 282, SD]), a sens 'szalbierz' uznano za przestarzały. W USJP natomiast w ogóle nie został ujęty. Zatem biblijne znaczenie, obecne w języku od staropolszczyzny, wyparło treść, która w słownikach rejestrujących dawną polszczyznę traktowana była jako dominująca. Za przyczynę usunięcia tego sensu uznać należy słabnącą w XIX i XX wieku rolę wędrownych iluzjo-

3 W SW odnotowany został także leksem cudodziej, uznany za przestarzały. Jednostki tej nie poświadczono jednak w żadnym leksykonie rejestrującym wcześniejsze słownictwo. W wątpliwość należy zatem podać jej obecność w polskiej leksyce.

4 Według Andrzeja Bańkowskiego bezpośrednim wzorem tych jednostek był staroruski rzeczownik čudtvorec, stanowiący przekład greckiego thaumatorgós [SBań]. 
nistów, którzy na ogół wybierali w tym okresie działalność teatralną [Krótki 2016]. Obecnie możliwe są jednak ironiczne użycia z leksemem cudotwórca, por. np. „Nie zrobię tego. Nie jestem cudotwórcą”.

Bardzo podobną historię do badanych wyżej jednostek miały ich żeńskie odpowiedniki, tj. cudotwórczyna [SL] i cudotwórczyni [SWil] - wpierw dotyczyły one świętej kobiety, czyniącej cuda, z kolei około XIX, początku XX wieku oznaczały 'oszustkę', a w połowie XX, na początku XXI stulecia 'kobietę czyniącą cuda'.

\subsection{Leksemy cudotwórstwo, cudotworność}

Znaczenia compositów cudotwórstwo i cudotworność (leksem rejestrowany po raz ostatni w SL) dalekie były od treści 'tworzenie cudów'. Od zawsze leksemy te stanowiły nazwę zdolności, irracjonalnego daru. Wpierw umiejętność tę wiązano wyłącznie z osobą świętą, np. „Patrz na święte poznasz jaki jest Pan Bog ktory na nich cudotwórstwo, wszechmocność, miłosierdzie, szczodrobliwość, łaskawość długocierpliwość, srogość i sprawiedliwość swoję daleko znaczniej niż indziej pokazować raczy" [Skar. Żyw A3, SXVI]. Z czasem wyrazy cudotwórstwo i cudotworność poza ‘bożym darem' zaczęly oznaczać również 'czarnoksięstwo i magię' [zob. Krótki 2017]. W artykule hasłowym ujętym w SL pojawia się nawet podział cudotwórstwa na: „cudowne od Boga; cudotwórstwo przyrodzone albo i nabyte, dowcipem, nauką" i „,magia, cudotworność zabobonna, czartowska". Trudno jednoznacznie orzec, jak długo znana była cytowana wyżej klasyfikacja, wszak jeszcze w połowie XX wieku zdarzały się użycia, w których cudotwórstwo rozumiano jako 'czarnoksięstwo’, por. np. „Ludzkość żyła i działała w złudzeniu, że świat jest pełen sił tajemniczych, że na świat można wpłynąć magią, cudotwórstwem, czarami, zaklęciami itp." [Zawadz. Wiad. X, 3, SD]. Obecnie leksem ten utracił sensy wiązane z kategorią MAGIA. Współcześni polscy leksykografowie opatrzyli go nawet kwalifikatorem książowy.

\subsection{Czasownik cudotworzyć}

Co ciekawe, czasownik cudotworzyć poświadczony został dopiero w SL. W żadnym jednak leksykonie (ani w SWil, ani w SW) nie został odnotowany jakikolwiek przykład użycia tej jednostki. Niewykluczone zatem, że czasownik ten stosowano marginalnie.

\subsection{Leksem cudopręty}

Kompozycja cudopręty 'mający cudny pręt' to klasyczny przykład neologizmu, użyty przez Jana Rybińskiego w Gęśli w odniesieniu do osoby Mojżesza: 
„I ciebie szkoda milczeć o gromado święta, ktorym dech zmarłym mnoży. Cnota skrzydłopięta. Tą Mojżesz cudo pręty, tą Taresa plemię słyną" [Ryb. Geśli D4, SXVI]. Wyraz ten odnotowany został tylko w powyższym fragmencie, niemniej warto zauważyć, że jego obecność stanowi potwierdzenie tezy o niesłabnącym dążeniu poetów XVI i XVII wieku do tworzenia własnych złożeń [Klemensiewicz 1985: 308; Kamper-Warejko 2009: 232-234].

\subsection{Leksem cudowidz}

Analogicznie do formacji cudopręty powstało compositum cudowidz 'ten, kto widzi, ogląda cuda'. Za autora tego złożenia uznaje się Stanisława Orzechowskiego - historyka, a zarazem twórcę pism politycznych i biograficznych, takich jak np. Żywot i śmierć Jana Tarnowskiego, kasztelana krakowskiego, hetmana wielkiego koronnego. We wspomnianym wyżej dziele czytamy: „Nuż zasię owe mowy $[\ldots]$ niewolnicy i cudowidzowie Azjatyccy: i ci posłom waszej K.M. zadawali, jakoby uszczypując, że wasza krol M. Tatary, obrzezańce w okowach zatrzymawać raczysz" [Orz. Jan 88, SXVI]. Trudno nie zauważyć, że w cytowanym fragmencie leksem cudowidz miał nacechowanie ironiczne i najprawdopodobniej oznaczał 'osobę zabobonną'. Z czasem zakres użyć tej formacji rozszerzył się, w SL i SWil leksem cudowidz znaczy bowiem 'tego, kto widzi cuda' [SW]. W SW uznany został natomiast za przestarzały.

\subsection{Leksem cudowisko}

W polszczyźnie XVIII, XIX i XX wieku funkcjonował wyraz cudowisko, utworzony od rzeczownika cud na wzór formacji widowisko.

W SL leksem ten zdefiniowany został jako 'widowisko za cud uchodzące'. Wydawać by się zatem mogło, że wyraz ten stanowił będzie synonim leksemu cud. Przekonanie to wzmacnia fakt, że cudowisko stanowiło nieraz nazwę niespotykanego zjawiska przyrodniczego, niepospolitego zdarzenia, dziwnej istoty, potwora, także osoby różniącej się swym zachowaniem lub/i wyglądem od ogółu, np. „Uczony ten prawdziwym był swoich czasów cudowiskiem” [Mon. 65, 549, SL]. Tymczasem po prześledzeniu szerszych kontekstów użycia tej jednostki okazuje się, że miała ona charakter ironiczny.

Ironia formacji cudowisko zawarta była w jej sufiksie (-isko), który od prasłowiańszczyzny [SPsł] poza nazwami miejsc tworzył augmentatiwa, nierzadko o odcieniu ujemnym, pogardliwym, ironicznym (por. współczesne dziewczynisko, pannisko, dziadzisko). Cudowisko było zatem hiperbolą osoby lub zjawiska, które w opinii tylko pewnej grupy ludzi uchodziło za nadzwyczajne, np. „Zaszły rozliczne w Polszcze cudowiska. Widziano nad Krakowem 
światłość jakąś na kształt księżyca z rozdzielonego na krzyż nieba wychodzącą" [Narusz. Hist. IV, 97, SD].

\subsection{Leksem cudotwór}

Niezwykle ciekawą historię miał leksem cudotwór, poświadczony po raz pierwszy w SL. Wyraz ten powstał na skutek kontaminacji dwóch rzeczowników: cud i stwór, dlatego oznaczał prymarnie 'potwora', np. ,Nieprzyjaciel, co zmyślne układa postury przyjaciela, jest mi cudotwór natury” [Min. Auz. 119, SL]. Pojawienie się tej jednostki nie było jednak przypadkowe. Utworzono ją właśnie wtedy, kiedy bazowy cud utracił sens 'monstrum'.

Znaczenie to absorbował nowo powstały cudotwór, który do końca XIX wieku stanowił nazwę istoty dziwnej, przerażającej. Później zaczęto jednostkę tę utożsamiać z cudem, por cudotwór 'cudowne zjawisko, cud' [SW], natomiast w połowie XX wieku stał się cudotwór nazwą osoby wybitnej, np. „Dziełko jego o Żeromskim np. jest najpiękniejsze, jaki o tym poecie napisano, a jednak najbardziej zdziwić i przerazić musiało samego Żeromskiego którego przeistoczył w jakiegoś cudotwora tajemnych, a niezwykłym jemu samemu potęg kosmicznych" [Irzyk. Czyn. 270, SD]. Obecnie wyraz ten nie jest ani używany, ani notowany w leksykonach.

\subsection{Jednostki cudostawny, cudostawnie}

Kompozycje cudosławny 'słynący cudami' i cudosławnie 'w sposób słynący cudami’ z całą pewnością były indywidualizmami. Zastosował je Ksawery Chodkiewicz w wierszu Stanisław Kostka: „Mąż ten po dziś dzień wielom świeci cudosławnie" [Chod. Kost. 65, SL, SWil]. Jednostki te nie pojawiały się w tekstach innych autorów, a na dodatek opatrzone zostały w SWil kwalifikatorem nieużywany.

\subsection{Leksem cudomówny}

Do indywidualizmów poetów doby średniopolskiej zaliczyć należy także zrost cudomówny 'mówiący o cudach' notowany przez Grzegorza Knapiusza. Wyraz ten poświadczony został w tezaurusie wspomnianego leksykografa oraz w SL, SWil i SW, niemniej w żadnym spośród wymienionych opracowań nie ujęto przykładów użycia. Nie można zatem wnioskować o tym, jakoby leksem cudomówny był kiedykolwiek używany w języku literackim bądź potocznym. 


\section{Leksemy implikujące „coś” dziwnego, głupiego, kuriozalnego}

\subsection{Leksemy cudować i cudować się}

W części pierwszej niniejszego szkicu, dotyczącej analizy leksemu cud, była mowa o tym, że frazeologizmy robić cuda i czynić cuda w niektórych XVI-wiecznych kontekstach miały nacechowanie ironiczne, znaczyły bowiem 'robić dziwne lub straszne rzeczy'.

Przywołana treść stanowiła dominantę semantyczną leksemu cudować, powstałego na bazie rzeczownika cud, np.: „Cudujesz z czeladzią bez końca, jeśli będziesz tak cudował, nie utrzymasz sługi" [Oss. Wyr., SL]. Niewykluczone jest jednak to, że czasownik, o którym mowa, utworzony został na skutek „ściągnięcia” do jednego wyrazu całego zwrotu robić (czynić) cuda, wszak jego jedyną, możliwą parafrazą słowotwórczą był powyższy frazeologizm.

Na początku XX wieku treść analizowanego czasownika rozszerzyła się. W zależności od kontekstu oznaczał on bowiem 'robić dziwne rzeczy', 'dziwaczeć, stawać się dziwnym', 'kaprysić', 'niszczyć'. Wszystkie nowe, właściwe dla początku XX stulecia, sensy rozwinęły się ze znaczenia 'robić dziwne rzeczy' (na skutek derywacji semantycznej). Najbardziej stabilny (spośród wymienionych treści) okazał się jednak sens 'kaprysić'. W tym bowiem znaczeniu leksem cudować funkcjonuje nadal w języku potocznym.

Z kolei czasownik cudować się, poświadczony również po raz pierwszy w SL, przez całą swą historię oznaczał 'odczuwać zdziwienie'. Na podstawie zebranych przykładów wywnioskować można nawet, że leksem ten do końca XIX wieku pełnił funkcję synonimu dziwić się, np. „Pierwszy raz w życiu wschód słońca zobaczywszy, cudował się, ani się nacudował” [Oss. Wyr., SL]. W SW uznany został natomiast za rzadki.

\subsection{Leksemy cudak, cudaczek, cudaczka, cudownik}

Mimo że rzeczowniki cudownik i cudak to derywaty utworzone na podstawie rzeczownika cud, już na początku swoich dziejów znaczyły one najczęściej 'osobę śmieszną, dziwaka' (np. „Spostrzegłszy go krzyczy: ach! cóż to za cudak” [Teat. 34. 62, SL]). Treści 'kuglarz’ (np. „Nie trzeba lekko ważyć ludzi, bo pod postacią błaznów i cudaków biegają" [Kłok. Tur. 182, SL]), 'cudotwórca' („Nie masz większego cudaka nad mojego świętego Antoniego. Ej panie Bracie, nie igraj z świętym Mikołajem, bo i on wielki cudak" [Oss. Wyr., SL]) rejestrowane były incydentalnie. Nawet połączenie święty cudak miało nacechowanie ironiczne, dotyczyło wszak dewoty, np. „Święty cudak nie wie, co począć w kościele, klęka, krzyżem leży, czołem bije, w piersi się grzmota, policzkuje się, ręce wyciąga w górę i w poprzek, obrazki liże" [Oss. Wyr., SL]. 
Najwyraźniej rzeczowniki cudownik, cudak (i powstałe od tegoż wyrazu cudaczek i cudaczka [SL]) bardzo szybko skojarzone zostały z czasownikiem cudować. Rozumiano je bowiem jako 'ten, kto cuduje, czyli robi dziwne rzeczy’. Od początku XX wieku natomiast za jedyne znaczenie badanych formacji uznaje się 'dziwak', z tym że w SD leksem cudownik nie jest już rejestrowany.

\subsection{Leksemy cudaczny, cudacki, cudactwo, cudaczyć}

Bazą słowotwórczą wyrazów cudaczny, cudacki, cudactwo oraz cudaczyć jest analizowany wyżej rzeczownik cudak, który od początku był nazwą odmieńca. Nie budzi zdziwienia to, że utworzone na jego podstawie derywaty wiązane były z kategorią DZIWACTWO. Przymiotniki cudaczny i cudacki znaczyły ‘dziwny, chimeryczny’ („Każdy uważa w sprawach cudzych coś, co mu się zdaje cudaczne i pełne chimer” [Cyank. Log. 85, SL]), rzeczownik cudactwo - 'cudackie postępowanie' (SL), natomiast czasownik cudaczyć (cudaczé́) - 'zostać dziwakiem' (,Miło było z nim żyć, ale teraz tak zcudaczał, że nie sposób mu dogodzić" [Oss. Wyr, SL]).

Spośród wszystkich wymienionych derywatów znaczenie zmienił tylko jeden wyraz - rzeczownik cudactwo. Od początku XX wieku leksem ten poza 'dziwnym, odbiegającym od pewnej, przyjętej normy zachowaniem' charakteryzował także 'rzecz dziwną, śmieszną' (por. np. „Coś ty za cudactwo ulepił?” $[\mathrm{SW}])$. W połowie tego samego stulecia sens sekundarny stał się jedynym znaczeniem badanego rzeczownika. Referowany stan utrzymuje się nadal.

\subsection{Leksemy cudacznie, po cudacku, cudaczność}

Derywaty cudacznie i cudaczność miały znaczenia pokrewne względem swojej podstawy słowotwórczej - przymiotnika cudaczny 'dziwny, chimeryczny'. Odnotowany na początku XX wieku rzeczownik cudaczność był synonimem badanego wcześniej wyrazu cudactwo, zatem analogicznie do tegoż leksemu prymarnie znaczył 'cudackie postępowanie', natomiast w połowie XX stulecia - 'dziwactwo'. Z kolei przysłówki cudacznie i po cudacku (tylko w SWil i SW) zawsze rozumiane były jako 'dziwacznie; na sposób cudaka'.

\subsection{Przymiotnik cudośny}

W XVIII i XIX wieku obecny był także w polszczyźnie przymiotnik cudośny. Nie sposób jednak znaleźć jego podstawy słowotwórczej, żaden bowiem spośród zgromadzonych wyrazów w połączeniu $\mathrm{z}$ formantem -ny nie daje postaci cudośny. Najwyraźniej badany leksem utworzony został na bazie niepoświadczonego w tekstach wyrazu o temacie słowotwórczym kończącym się na $-s$ lub $-s ́$. 
Niemniej cudośny zawsze oznaczał 'cudaczny, dziwny', sytuował się zatem w kategorii DZIWACTWO.

$* * *$

Zebrane elementy badanego gniazda słowotwórczego koncentrowały się wokół dwóch pól semantycznych: ZJAWISKO NADPRZYRODZONE i DZIWACTWO. Druga kategoria, zawierająca zaledwie 14 jednostek (pierwsza liczyła 36 wyrazów), rozwinęła się dopiero w XVIII stuleciu, chociaż już w XVI wieku leksem cud stosowany bywał w znaczeniu ironicznym.

Staro- i średniopolskie derywaty leksemu cud wiązane jednak były najczęściej z 'pięknem', 'doskonałością', 'grzecznością', także z 'magią', 'czarnoksięstwem' oraz 'szalbierstwem'. Do wyparcia ostatnich treści przyczyniły się rozwój nauki oraz zmiana warunków życia, które doprowadziły do tego, że nikt już nie wiąże dawnych iluzjonistów z cudotwórcami.

Podczas analiz zgromadzonych jednostek nie zawsze było możliwe jednoznaczne włączenie konkretnego elementu do zbioru nazw wiązanych ze zjawiskiem irracjonalnym lub do grupy leksykalnej implikującej „coś” kuriozalnego. Znaczenia wielu leksemów uzależnione bowiem były od kontekstu wyrazowego [Kiklewicz 2016]. Można nawet tutaj posłużyć się teorią „oscylujących” wypadków Georga Sterna, wedle której ten sam element leksykalny w danym kontekście ma dwa znaczenia [Apresjan 1980: 240]. Przykładowo wykrzyknienie To cud! może oznaczać, że w mniemaniu nadawcy komunikatu doszło do zjawiska nadprzyrodzonego albo że podmiot mówiący z ironią odniósł się do rzeczy lub zjawiska pozornie odbiegającego od normy.

\section{Bibliografia}

\section{Źródta}

ESJPBań - Bańkowski Andrzej (2000), Etymologiczny słownik języka polskiego, t. 1-2, PWN, Warszawa.

SBor - Boryś Wiesław (2005), Słownik etymologiczny języka polskiego, Wydawnictwo Literackie, Kraków.

SBr - Brückner Aleksander (1927), Słownik etymologiczny języka polskiego, Krakowska Spółka Wydawnicza, Warszawa.

SD - Doroszewski Witold, red. (1958-1969), Słownik języka polskiego, t. 1-11, PWN, Warszawa. 
SKras - Krasiński Adam Stanisław (1888), Słownik synonimów polskich, Akademia Umiejętności w Krakowie, Kraków.

SL - Linde Samuel Bogumił (1807-1814), Słownik języka polskiego, t. 1-6, Zakład Ossolińskich, Warszawa.

SSław - Sławski Franciszek (1955-1983), Słownik etymologiczny języka polskiego,

Nakładem Towarzystwa Miłośników Języka Polskiego, Kraków.

SStp - Urbańczyk Stanisław, red. (1966-2000), Słownik staropolski, t. 1-11, Ossolineum, Warszawa.

SWil - Zdanowicz Aleksander, Bohusz-Szyszko Michał, red. (1861), Słownik języka polskiego, t. 1-2, wydano nakładem i kosztem Maurycego Orgelbranda, Wilno.

SXVI - Mayenowa Maria Renata, red. (1966), Słownik polszczyzny XVI wieku, Ossolineum, Wydawnictwo PAN, Wrocław.

SXVII - Bańko Mirosław i in., red. (1999-2014), Elektroniczny słownik XVII i pierwszej połowy XVIII wieku, http://sxvii.pl/ [dostęp: 15 maja 2015].

USJP - Dubisz Stanisław, red. (2003), Uniwersalny słownik języka polskiego, PWN, Warszawa.

\section{Literatura}

Apresjan Jurij D. (1980), Semantyka leksykalna. Synonimiczne środki języka, przeł. Andrzej Markowski, Zofia Kozłowska, Zakład Narodowy im. Ossolińskich, Wrocław.

Handke Kwiryna (1976), Budowa morfologiczna i funkcje compositów polskich (z uwzględnieniem innych języków zachodnioeuropejskich), Zakład Narodowy im. Ossolińskich, Wrocław.

Janowska Aleksandra (2000), Związki frazeologiczne w funkcji podstaw słowotwórczych, w: Stowotwórstwo a inne sposoby nominacji, red. Krystyna Kleszczowa, Ludwig Selimski, Wydawnictwo Naukowe i Artystyczne Gnome, Katowice.

Kamper-Warejko Joanna (2009), ,, Gęśli” Jana Rybińskiego - świadectwo normalizacji polszczyzny renesansowej Torunia, „Linguistica Copernicana”, nr 2, s. 223-241.

Kiklewicz Aleksander (2016), Granice i pogranicza (bezgranicza?) językoznawstwa, „Prace Językoznawcze”, 18/2, s. 67-81.

Klemensiewicz Zenon (1985), Historia języka polskiego, t. 2, PWN, Warszawa.

Krótki Zuzanna (2016), Sztuka iluzji w dawnych polskich jednostkach leksykalnych, „Kwartalnik Językoznawczy”, s. 1-18.

Krótki Zuzanna (2016), CZARY w leksyce dawnej polszczyzny, „Słowo. Studia językoznawcze", t. 7, s. 36-50.

Puzynina Janina (1961), „, Thesaurus” Grzegorza Knapiusza. Siedemnastowieczny warsztat pracy nad językiem polskim, Zakład Narodowy im. Ossolińskich, Wrocław. 


\section{Zuzanna Krótki}

\section{Lexeme cud (miracle) and his derivatives in history of Polish language}

In the article the fifty lexical units were analysed and attributed to the word family of the noun - cud (miracle). The general scope of the analysis was created by the semasiological method. Stemming from the etymology, upon investigation by which methods the particular wordforms acquired new senses it was characterized by movements and objective, which these modifications served.

As it turned out the researched lexical units concentrated around such semantic fields as: WONDER and STRANGENESS. The second category (field) developed not until the 18th century. Earlier the analyzed derivatives implied such words as: 'beauty', 'perfectness', 'politeness', 'magic', 'wizardry' and 'fraud'. The life changing events and the developing knowledge caused the eradication of last written material and as it happened nobody correlates the jugglers with the miracle makers.

KEYwords: history of Polish language; the changing in meanings; semantics; lexeme cud (miracle) and its derivatives; diachronic.

dr Zuzanna Krótki - absolwentka studiów doktoranckich Uniwersytetu Śląskiego w Katowicach; zainteresowania naukowe: zagadnienia historycznojęzykowe dotyczące głównie leksykologii, semantyki i frazeologii historycznej; ponadto zagadnienia z zakresu dydaktyki języka polskiego. 
